\title{
Discovery of novel $\alpha$-amylase inhibitors using structure-based drug design
}

\author{
Jamil Al-Asri", Gerhard Wolber \\ From 9th German Conference on Chemoinformatics \\ Fulda, Germany. 10-12 November 2013
}

$\alpha$-Amylase is an endoamylase and belongs to glycoside hydrolase family 13 (GH 13) according to the classification of carbohydrate-active enzymes [1]. It initiates starch hydrolysis into smaller oligomers. Inhibitors of this enzyme are of pharmacological importance as $\alpha$-amylase is considered as attractive target for treating elevated post-prandial blood glucose levels resulting in obesity and type II diabetes. Besides the application as a drug, it is highly interesting to classify nutritional components, such as food additives or secondary plant metabolites with respect to their modulation of $\alpha$-amylase.

We present a model that predicts the affinity of small organic molecules to $\alpha$-amylase. On the basis of available crystal structures (Figure 1) [2], we developed a virtual screening workflow for the identification of novel non- peptidic, non-carbohydrate $\alpha$-amylase inhibitors. In

addition to virtual screening using structure-based 3D pharmacophore models [3], molecular docking and clustering for diversity selection have been applied as postscreening filters. Fourteen virtual hits were purchased and tested in vitro using a kinetic assay with p-Nitrophenyl- $\alpha-d-$ maltopentaoside (PNPG5) as a chromogenic substrate. Three of those fourteen compounds showed concentration-dependent inhibition with promising $\mathrm{IC}_{50}$ values (hit rate: $21 \%$ ).

Published: 11 March 2014

\section{References}

1. Cantarel BL, Coutinho PM, Rancurel C, Bernard T, Lombard V, Henrissat B: The carbohydrate-active enzymes database (cazy): An expert resource for glycogenomics. Nucleic Acids Res 2009, 37:D233-D238.

2. Qin X, Ren L, Yang X, Bai F, Wang L, Geng P, Bai G, Shen Y: Structures of human pancreatic alpha-amylase in complex with acarviostatins:

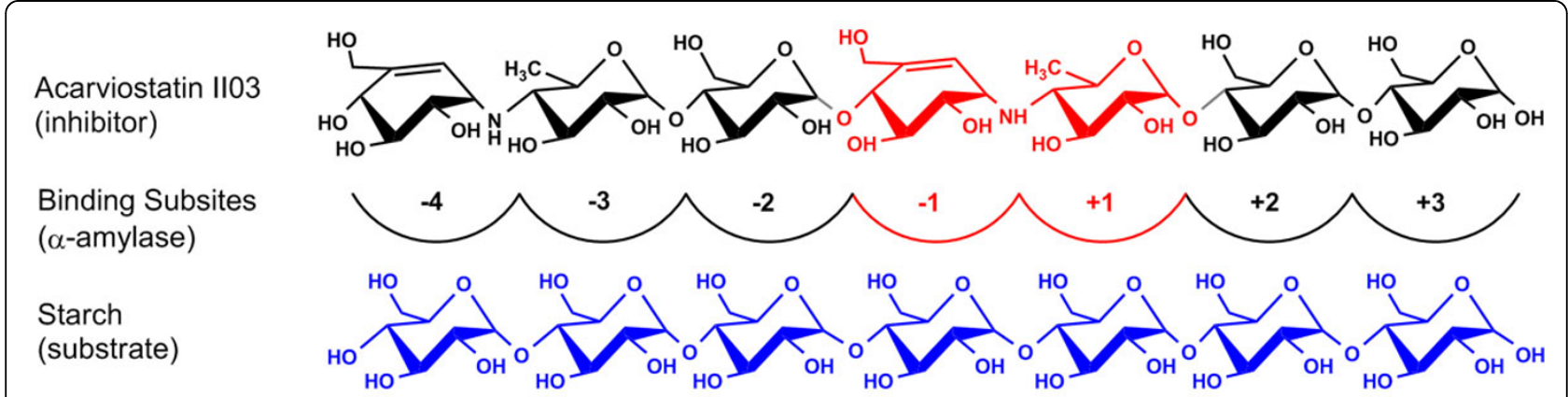

Figure 1 Subsites of $\alpha$-amylase with Acarviostatin II03 inhibitor, (ki 14 nM) (PDB entry: 3OLE) and starch. Site of cleavage is between subsites -1 and +1 .

\footnotetext{
* Correspondence: jmasa75@zedat.fu-berlin.de

Computer-Aided Molecular Design, Pharmaceutical Chemistry Department,
}

Freie Universität Berlin, Berlin, 14195, Germany 
Implications for drug design against type II diabetes. J Struct Biol 2011, 174(1):196-202.

3. Wolber G, Langer T: Ligandscout: 3-d pharmacophores derived from protein-bound ligands and their use as virtual screening filters. J Chem Inf Model 2005, 45(1):160-169.

doi:10.1186/1758-2946-6-S1-P50

Cite this article as: Al-Asri and Wolber: Discovery of novel $\alpha$-amylase

inhibitors using structure-based drug design. Journal of Cheminformatics 2014 6(Suppl 1):P50.

\section{Publish with ChemistryCentral and every scientist can read your work free of charge \\ "Open access provides opportunities to our colleagues in other parts of the globe, by allowing anyone to view the content free of charge." \\ W. Jeffery Hurst, The Hershey Company. \\ - available free of charge to the entire scientific community \\ - peer reviewed and published immediately upon acceptance \\ - cited in PubMed and archived on PubMed Central \\ - yours - you keep the copyright \\ Submit your manuscript here: \\ http://www.chemistrycentral.com/manuscript/<smiles>c1ccccc1</smiles> 